\title{
Analysis of causes of hospitalization and functional fitness of patients in a rehabilitation department
}

\section{Analiza przyczyn hospitalizacji i sprawności funkcjonalnej pacjentów kliniki rehabilitacji}

\author{
Beata Szczepanowska-Wołowiec ${ }^{1,2}$, Katarzyna Rurarz², Magdalena Adamczyk ${ }^{3}$, Paulina Sztandera ${ }^{4}$, \\ Grażyna Ściegienna-Zdeb², Ireneusz Kotela ${ }^{1,5}$
}

\author{
'Department of Rehabilitation in Disease of the Locomotor, Institute of Physiotherapy, Faculty of Medicine and Health Science, \\ Jan Kochanowski University, Kielce, Poland \\ Head of the Department: Prof. JKU Ireneusz Kotela MD, PhD \\ 2Rehabilitation Department, Regional Polyclinical Hospital, Kielce, Poland \\ Head of the Department: Grażyna Ściegienna-Zdeb MD \\ ${ }^{3}$ Student of Physiotherapy, Jan Kochanowski University, Kielce, Poland \\ ${ }^{4}$ Department of Neurological Rehabilitation, Regional Polyclinical Hospital, Kielce, Poland \\ Head of the Department: Justyna Sieczka MD \\ ${ }^{5}$ Clinical Department of Orthopedics and Traumatology, Central Clinical Hospital of the Ministry of the Interior, Warsaw, Poland \\ Head of the Department: Prof. CCHMI Ireneusz Kotela MD, PhD
}

Key words: causes of hospitalization, assessment of functional fitness, Up and Go test.

Słowa kluczowe: przyczyny hospitalizacji, ocena sprawności funkcjonalnej, test „wstań i idź”.

\begin{abstract}
Introduction: The increase observed in the size of the elderly population is related to an increase in the average life span. Involutional changes in the human body concern all organs and systems. Multiple morbidities, to a considerable extent, contribute to the limitation of motor fitness. Recently, a change has been noted in the age of patients hospitalized in rehabilitation departments. The majority of these patients are aged over 60, and are admitted due to aggravation of polyarticular pain, arterial hypertension, problems with knee or hip joints (degeneration, pain), ischemic heart disease, or degenerative polyarthritis. Hospitalization in the rehabilitation department contributes to the improvement in their state of health.

Aim of the research: The objective of the study was to analyse the causes of hospitalization and functional fitness of patients hospitalized in the Rehabilitation Department at the Regional Polyclinical Hospital in Kielce.

Material and methods: The study included 102 patients of the Rehabilitation Department at the Regional Polyclinical Hospital in Kielce, 79 female and 23 male, mean age 72.6.

Results: The majority of patients (74\%) were admitted to the department with the diagnosis of aggravation of polyarticular pain, followed by arterial hypertension (as many as 64\%), problems concerning knee and hip joints (degeneration, pain), ischemic heart disease, and polyarticular changes.

Conclusions: Patients aged over 60 comprised the largest group in the study, and the dominant causes of hospitalization were aggravation of pain and arterial hypertension.
\end{abstract}

\section{Streszczenie}

Wprowadzenie: Wzrost liczby osób w podeszłym wieku wiąże się z wydłużeniem średniej długości życia. Zmiany inwolucyjne zachodzące w organizmie człowieka dotyczą wszystkich narządów i układów. Wielochorobowość w znacznym stopniu przyczynia się do ograniczenia sprawności ruchowej. Obecnie na oddziałach rehabilitacyjnych widoczna jest zmiana wieku hospitalizowanych pacjentów. Większość z nich to osoby powyżej 60. roku życia. Rozpoznania, z jakimi większość pacjentów trafia na oddział, to: zaostrzenia dolegliwości bólowych wielostawowych, nadciśnienie tętnicze, problemy ze stawami kolanowymi i biodrowymi (zwyrodnienie, ból), choroba niedokrwienna serca, zmiany zwyrodnieniowe wielostawowe. Pobyt na oddziale rehabilitacyjnym przyczynia się do poprawy stanu zdrowia.

Cel pracy: Analiza przyczyn hospitalizacji i sprawności funkcjonalnej pacjentów przebywających w Klinice Rehabilitacji Wojewódzkiego Szpitala Zespolonego w Kielcach.

Materiał i metody: Badania przeprowadzono u 102 osób będących pacjentami Kliniki Rehabilitacji Wojewódzkiego Szpitala Zespolonego w Kielcach. Wśród badanych było 79 kobiet i 23 mężczyzn. Średnia wieku pacjentów wynosiła 72,6 roku. 
Wyniki: Najwięcej (74\%) pacjentów trafia na oddział z rozpoznaniem zaostrzenia dolegliwości bólowych wielostawowych, aż $64 \%$ pacjentów ma rozpoznane nadciśnienie tętnicze. Kolejną grupę stanowią pacjenci mający problemy ze stawami kolanowymi i biodrowymi (zwyrodnienie, ból), a następnie z chorobą niedokrwienną serca i zmianami zwyrodnieniowymi wielostawowymi. Wnioski: Najliczniejszą grupę pacjentów stanowią osoby powyżej 60. roku życia. Zaostrzenie dolegliwości bólowych i nadciśnienie tętnicze to główne rozpoznania u osób hospitalizowanych.

\section{Introduction}

Today, the problem of the ageing of the population is very frequently addressed. This natural process is inscribed in the course of ontogenesis, and results in many unfavourable changes which limit the compensatory and regenerative capabilities of the body. A gradual reduction of body reserves begins at the age of $30-40$, and progresses with the passage of time $[1,2]$.

Longitudinal studies have shown that at the age of over 50 , muscle mass is reduced by $6 \%$ per decade, on average, muscle strength decreases between the ages 50 to 60 by $1.5 \%$ annually, while at the age of over 60 , it decreases by $3 \%$ annually, on average. The reduction in muscle strength, motor coordination, balance disorders and multiple morbidities are the factors which hinder the maintenance of motor fitness in the elderly [3].

The elderly are the main group of patients admitted to the rehabilitation department. Low physical activity and senile changes in physiological control of postural and walking stability exert a considerable effect on the deterioration of motor fitness. Polypathology, polytherapy, and polypharmacy are the subsequent factors which greatly contribute to the limitation of fitness [4]. The most frequent pathologies observed among seniors are arterial hypertension, ischemic heart disease, degenerative and inflammatory joint diseases, overweight, malnutrition, diabetes and osteoporosis [5].

Involutional changes concern all organs and systems of the human body. With respect to the motor organ, changes in the muscular and skeletal systems seem to be most important, and affect patients' physical activity. Muscle mass, cross-section and density decrease with age, which is related to an increased content of intramuscular fat. Changes are also observed in the structure of collagen, which exerts an effect on muscle flexibility. A decrease in muscle strength is associated with a change in muscle innervation. The number of neurons in the spinal cord changes, there occurs a synaptic delay, and the process of motor neuron stimulation in the central nervous system (CNS) slows down, resulting in disturbances in responding to stimuli. The reduction in muscle strength is larger in the lower extremities, which considerably affects locomotion [6-8]. Ageing of the body contributes to the demineralization of bones, as well as to the loss of their flexibility. Rigidity of the connective tissue and joint capsule results in a reduction of the extent of motion in the joints [6]. Involutional changes in the nervous system lead to the slowing down of the thinking pro- cess, weakening of reflexes, and a decrease in muscle tension. Apart from motor functions, there occur psychological changes in seniors, problems with memory and cognitive functions, changes in the processes of thinking and perception, loss of emotions and interest, as well as personality disorders [1]. The reduction of muscle strength and neuromuscular coordination, and changes in flexibility and balance contribute to the deterioration of the functional fitness of patients.

Therefore, the task of physiotherapy will be to improve the state of health, delay the ageing process, increase functional fitness and improve the quality of life of the patients. Thus, it seems justifiable to carry out physical therapy targeted at improving walking and balance, and increasing muscle strength.

\section{Aim of the research}

Analysis of the causes of hospitalization and functional fitness of patients hospitalized in the Rehabilitation Department at the Regional Polyclinical Hospital in Kielce.

\section{Material and methods}

The study was conducted during the period 31 March to 10 April 2015, in the Rehabilitation Department at the Regional Polyclinical Hospital in Kielce, and included 102 patients, 79 female and 23 male, who expressed their written consent to participate in the research (Figure 1).

While analysing the age structure of patients participating in the study an age histogram was constructed. The youngest patient hospitalized in the department of the unit was a woman aged 45 , and the oldest was a woman aged 98. Table 1 and Figure 2 present the relevant statistics by age.

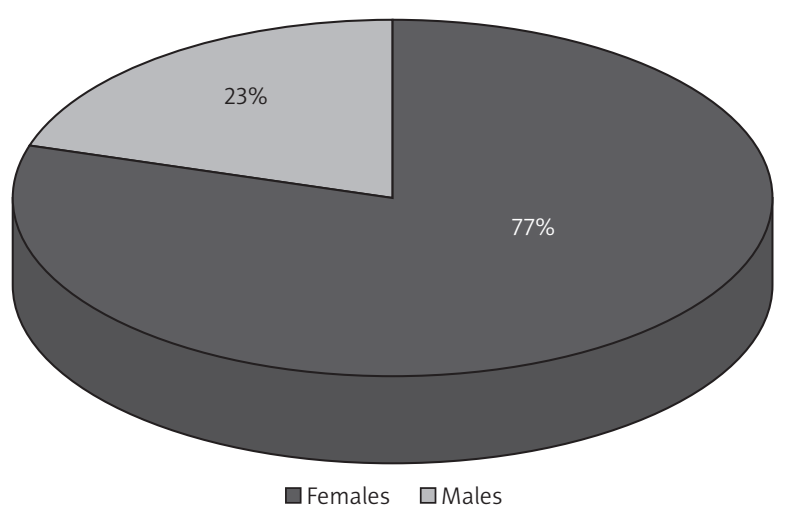

Figure 1. Structure of patients according to gender 
Table 1. Structure of patients according to age in years

\begin{tabular}{|cccc|}
\hline Minimum & Mean & Median & Maximum \\
45 & 72.6 & 73 & 98 \\
\hline
\end{tabular}

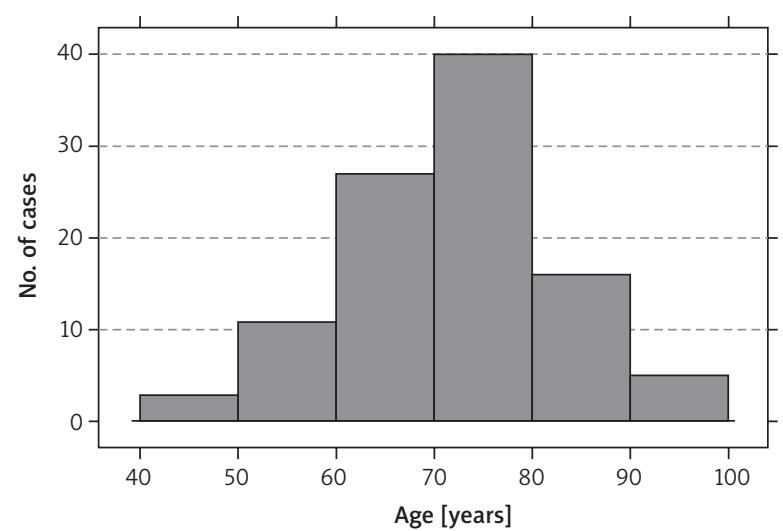

Figure 2. Structure of patients in the study by age

The majority of patients participating in the study were the elderly ( 90 patients), i.e. $88 \%$ of the patients hospitalized in the department, the majority of whom were female, mainly urban inhabitants with secondary school education (Table 2).

Table 3 presents the division according to the body mass index (BMI) based on the WHO classification [9]. It shows that $82 \%$ of patients were overweight or obese.

In accordance with the assumptions and the objective of the study, inclusion and exclusion criteria were adopted.

Inclusion criterion: patients of the Rehabilitation Department, patient's consent to conduct the study, ability to walk independently or with the use of orthopaedic equipment (crutches, walking frame).

Exclusion criterion: lack of consent to conduct the study, incomplete medical records, people who were not patients of the Rehabilitation Department.

At the first stage of research, a survey was conducted designed according to our own methodology. The survey contained 19 items in the form of open and closed questions. Subsequently, the patients performed the Up and Go test. This is a relatively simple test for the evaluation of walking and functional fitness.

The result of the test is the time needed to complete the task. Three attempts are always undertaken. The results obtained were subject to statistical analysis. The data of a quantitative character were characterised by the determination of the size of the group.

\section{Results}

Patients admitted to the department due to aggravation of polyarticular pain made up the largest proportion (74\%), and as many as $64 \%$ of patients suffered from arterial hypertension. The next largest group comprised patients with problems concerning knee and hip joints (degeneration, pain), followed by those with ischemic heart disease and degenerative polyarticular changes (Figure 3).

The mean number of disorders diagnosed in patients admitted to the department was $5 ; 21 \%$ of patients were diagnosed with 7 or more disorders; as many as $75 \%$ of patients were admitted to the department with at least 4 disorders diagnosed (Figure 4).

For all the cases available (102), a histogram was prepared pertaining to the time required for perfor-

Table 2. Structure of patients participating in the study

\begin{tabular}{|c|c|c|c|c|c|}
\hline \multirow{2}{*}{\multicolumn{2}{|c|}{$\begin{array}{l}\text { Structure of study group according to: gender, } \\
\text { age, education level, place of residence }\end{array}$}} & \multirow{3}{*}{$\begin{array}{c}\text { No. of } \\
\text { patients } \\
79\end{array}$} & \multirow{3}{*}{$\begin{array}{c}\text { Percentage } \\
77\end{array}$} & \multicolumn{2}{|c|}{ Orthopaedic aid } \\
\hline & & & & \multirow{2}{*}{$\begin{array}{c}\text { No. of patients } \\
22\end{array}$} & \multirow{2}{*}{$\begin{array}{c}\text { Percentage } \\
28\end{array}$} \\
\hline Gender & Females & & & & \\
\hline & Males & 23 & 23 & 7 & 30 \\
\hline \multirow[t]{4}{*}{ Age } & $<60$ & 12 & 12 & 4 & 33 \\
\hline & $60-69$ & 28 & 27 & 8 & 29 \\
\hline & 70-79 & 37 & 36 & 5 & 14 \\
\hline & $\geq 80$ & 25 & 25 & 12 & 48 \\
\hline \multirow[t]{4}{*}{ Education level } & Primary & 30 & 29 & 7 & 23 \\
\hline & Primary vocational & 20 & 20 & 2 & 10 \\
\hline & Secondary school & 42 & 41 & 18 & 43 \\
\hline & University & 10 & 10 & 2 & 20 \\
\hline \multirow[t]{2}{*}{ Place of residence } & Urban area & 73 & 72 & 21 & 29 \\
\hline & Rural area & 29 & 28 & 8 & 28 \\
\hline
\end{tabular}




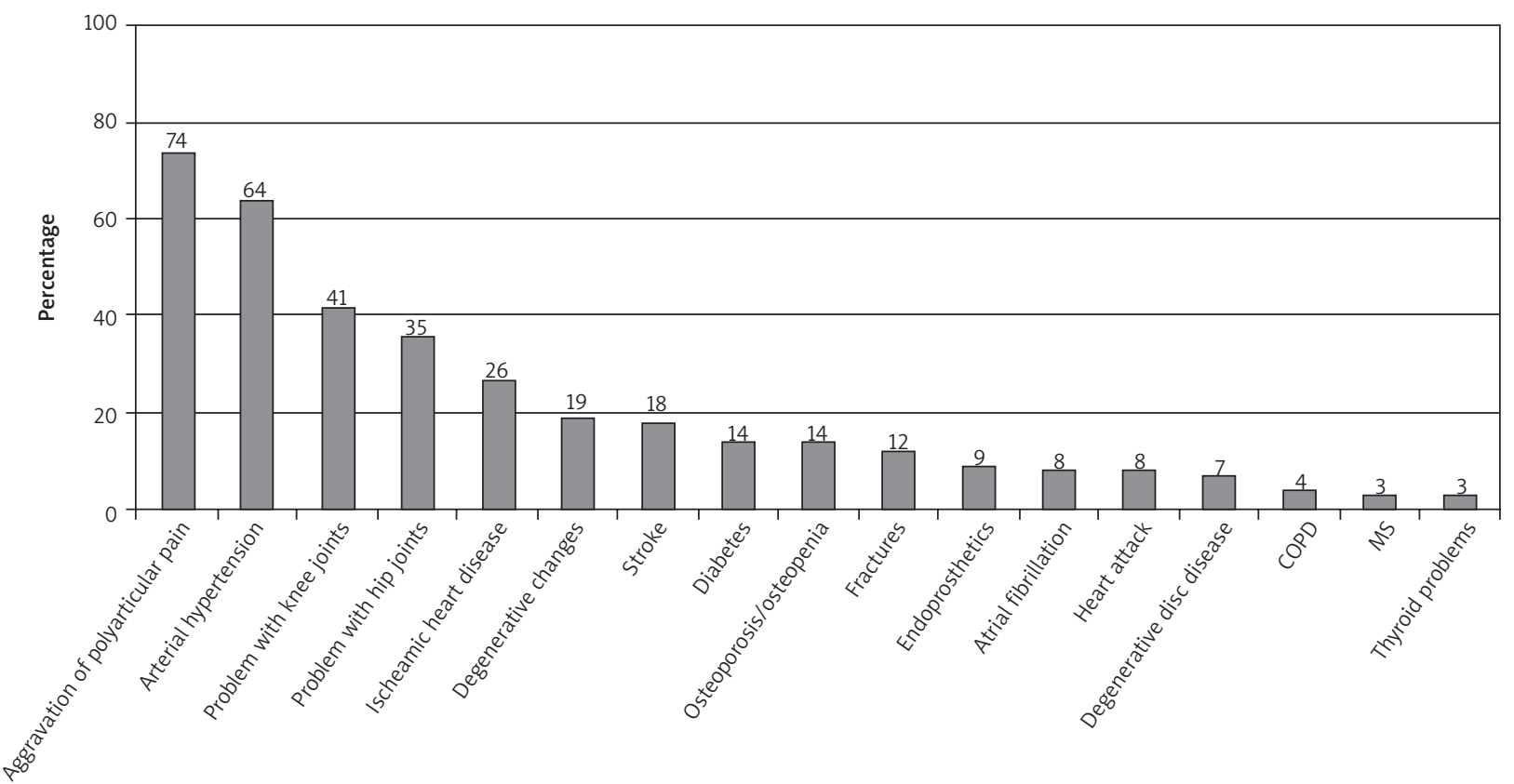

Figure 3. Diagnoses with which patients are admitted to the Rehabilitation Department

Table 3. Structure of patients according to body mass in$\operatorname{dex}(\mathrm{BMI})$

\begin{tabular}{|lcc|}
\hline BMI classes & No. of patients & Percentage \\
Underweight & 2 & 2 \\
Normal weight & 16 & 16 \\
Overweight & 36 & 35 \\
Obesity & 48 & 47 \\
\hline
\end{tabular}

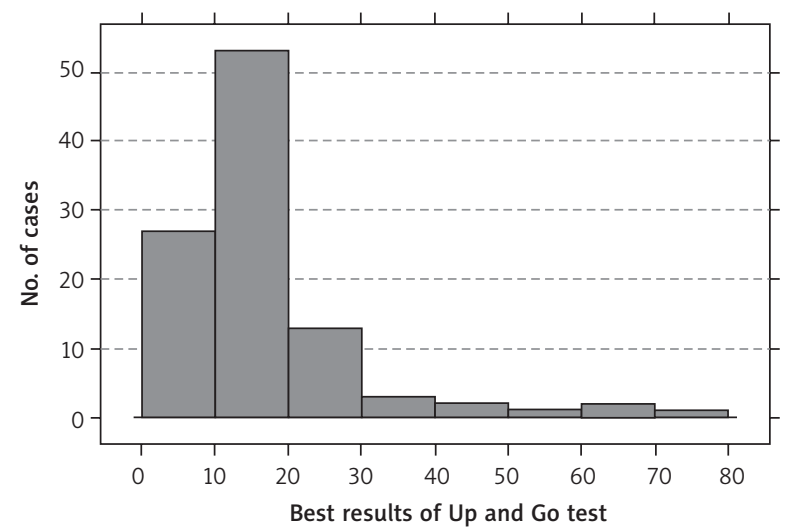

Figure 5. Histogram of time [s] required to perform the Up and Go test

mance of the Up and Go test. The best time obtained in three attempts was adopted as a result. Figure 5 shows that the majority of patients in the study needed $10-20 \mathrm{~s}$ to perform the test (Figures 5 and 6).

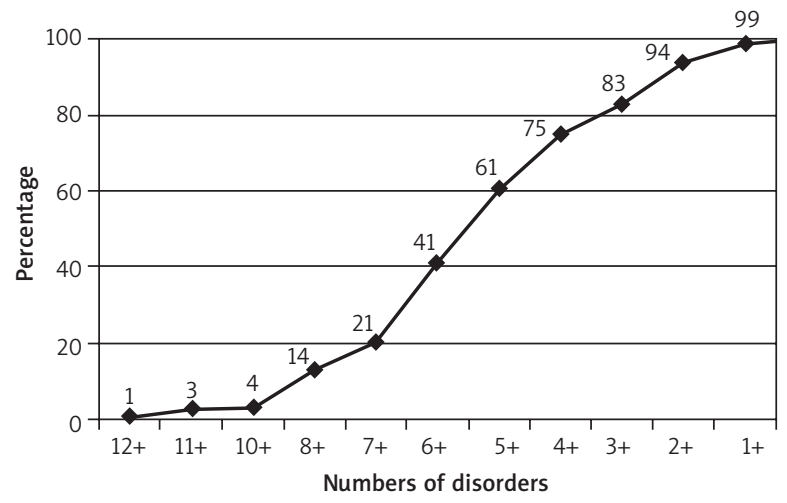

Figure 4. Number of disorders diagnosed in patients admitted to the department

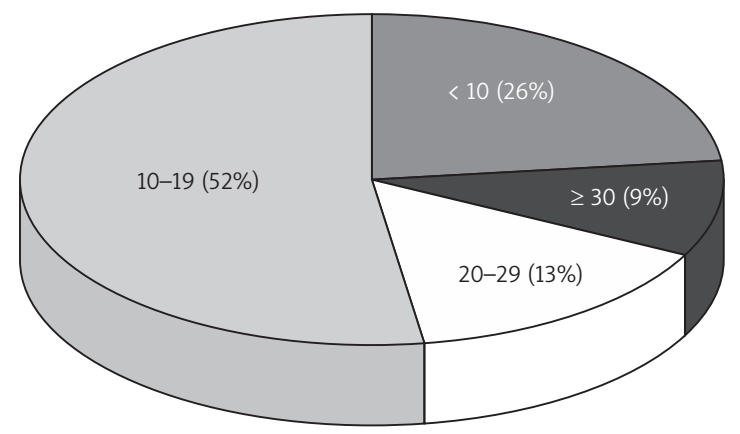

Figure 6. Results of Up and Go test

Only 27 patients performed the test during a time $<10 \mathrm{~s}$, the largest group (53 patients) performed the test within 10-19 s, 13 patients took 20-29 s, while 9 patients needed more than $30 \mathrm{~s}$ to perform the test, 
and these were mainly patients using orthopaedic aids (Figures 5 and 6).

\section{Discussion}

The progress in medical sciences and modern methods of treatment contribute to an increase in the average life span. Statistical prognoses by the Main Statistical Office assume that in 2020, 23\% of the population will be aged over 60 . In 2030, the number of the population aged over 65 will reach 8.2 million. A relatively rapid increase will be noted in the number of the population aged over 80 - from 1.3 to 1.6 million in 2020, and up to 2 million in 2030. According to the World Health Organization (WHO), a geriatric patient is a person with a minimum age of 60 , referred to a geriatrician, with the diagnosis of at least 4 chronic diseases. The WHO distinguishes with respect to old age: advanced age 60-75, senior age 75-90, and old age over $90[1,10]$.

In our own studies there prevailed patients at advanced and senior ages, and similar relationships were observed by Paszkiewicz et al. and Dzieża-Grudnik et al. $[10,11]$. The majority of patients were women, similar to observations of Arinzon et al. [12]. The most frequently reported cause of hospitalization was aggravation of pain concerning various joints, and consequently the deterioration of functional fitness of patients, which was also observed in the study by Paszkiewicz et al. [10]. Among the geriatric patients, a frequently diagnosed pathology was arterial hypertension, which was confirmed by our study and also found in the study by Żak and Gryglewska [4].

Degenerative joint disease was a disorder frequently observed among the elderly, which was also confirmed by our study.

Gajewska et al. [13] observed an increase in hospitalization due to obesity. In our study it was noted that $82 \%$ of patients hospitalized in the department were overweight or obese.

The majority of patients who used inpatient hospitalization were aged over 60 and characterized by multiple morbidities. A change of profile was clearly observed - from a general patient towards that of a geriatric patient. In addition, the occurrence of so-called 'geriatric giants' among patients hospitalized was characteristic. Involutional changes in the elderly are expressed by the prolongation of the time of performance of the Up and Go test, and consequently an increase in the risk of falling. That tendency was also observed in Zasadzka's et al. [14], Siu's et al. [15], Villafañe's et al. [16], and Żak's et al. [17] studies. Physical activity of elderly people in most cases is significantly reduced, and it is one of the important factors affecting so-called favourable aging, contributing to a delay in the aging process. Reduced physical fitness and muscle strength increase the risk of falls and all consequences related to this.
Maintenance of the functionalfitness of seniorscontributes to the improvement in the way of locomotion, and exerts an effect on postural stability - as demonstrated in our studies as well as those of Manckoundia et al. [18], da Silva et al. [19], and Howe et al. [20]. The natural aging process cannot be avoided, but may be delayed by physical activity. Research shows that systematic physical activity is beneficial for physical and mental health and reduces the effects of physical disability [21, 22].

The goal of effective rehabilitation is the reduction of pain, and maintenance and improvement of motor fitness, with consideration of limitations resulting from polypathology.

\section{Conclusions}

Patients hospitalized in the department were mainly at senior and advanced age. The largest group of hospitalized patients suffered from aggravation of pain and arterial hypertension. The largest group of hospitalized patients could independently go outdoors and did not need orthopaedic aids; however, in these patients an in-depth evaluation of the risk of falling is recommended. Continuation of studies which could assess the influence of physiotherapy on results of the Up and Go test is needed.

\section{Conflict of interest}

The authors declare no conflict of interest.

\section{References}

1. Halat B, Brudz D, Milewicz K, Pop T, Śliwiński Z. Wpływ ćwiczeń ogólnousprawniających na równowagę i chód osób $\mathrm{w}$ podeszłym wieku, przebywających $\mathrm{w}$ oddziale ZOL w Legnicy. Przegląd Medyczny Uniwersytetu Rzeszowskiego i Narodowego Instytutu Leków w Warszawie, Rzeszów 2014; 1: 84-96.

2. Michałkiewicz H, Wróbel J. Całościowa ocena geriatryczna - narzędzie ważne również dla fizjoterapeutów. Zamojskie Studia i Materiały 2012; 141: 91-6.

3. Krzymińska-Siemaszko R, Wieczorowska-Tobis K. Ocena sarkopenii u osób starszych - przyczynek do metodologii. Nowiny Lekarskie 2012; 81: 16-20.

4. Żak M, Gryglewska B. Upadki pacjentów geriatrycznych z nadciśnieniem tętniczym - ocena ryzyka dokonywana po roku od upadku. Nadciśnienie Tętnicze 2005; 9: 112-7.

5. Jajor J, Nonn-Wasztan S, Rostkowska E, Samborski W. Specyfika rehabilitacji ruchowej osób starszych. Nowiny Lekarskie 2013; 82: 89-96.

6. Podhorecka M, Kędziora-Kornatowska K, Sielski G. Zmiany inwolucyjne $\mathrm{w}$ układzie ruchu oraz ich konsekwencje wpływające na zmniejszenie aktywności fizycznej osób starszych. Pielęgniarstwo XXI Wieku 2011; 1: 35-38.

7. Skrzek A, Ignasiak Z, Domaradzki J. Zmiany inwolucyjne narządu ruchu a ryzyko złamań. Medycyna Fizykalna 2011; 17: 179-83.

8. Almehed K, Hetenyi S, Ohlsson C, et al. Prevalence and risk factors of vertebral compression fractures in female SLE patient. Arthritis Research Therapy 2010; 12: 153-60. 
9. http://apps.who.int/bmi/index.jsp?introPage=intro_3. html [16 VII 2015].

10. Paszkiewicz J, Wrońska I, Spisacka S, Staniszewska M, Ławnik A. Problemy opiekuńczo-pielęgnacyjne oddziału geriatrycznego. Med Ogól Nauki Zdrow 2014; 20: 320-4.

11. Dzieża-Grudnik A, Czekaj D, Wójcik-Bugajska, Grodzicki T. Upadki w trakcie hospitalizacji - częstość występowania i konsekwencje. Przegl Lek 2014; 71: 537-40.

12. Arinzon Z, Shabat S, Pelsakh A, Gepstein R, Berner YN. Gender differences influence the outcome of geriatric rehabilitation following hip fracture. Arch Gerontol Geriatr 2010; 50: 86-91.

13. Gilewska M, Goryński P, Wysocki MJ. Otyłość i cukrzyca typu 2 jako główne przyczyny hospitalizacji w polskich szpitalach w 2008 roku. Probl Hig Epidemiol 2011; 92: $132-6$.

14. Zasadzka E, Borowicz AM, Roszak M, Pawalczyk M Assessment of the risk of falling with the use of timed up and go test in the elderly with lower extremity osteoarthritis. Clin Interv Aging 2015; 10: 1289-98.

15. Siu KC, Rajaram SS, Padilla C. Impact of psychosocial factors on functional improvement in Latino older adults after Tai Chi exercise. J Aging Phys Activ 2015; 23: 120-7.

16. Villafañe JH, Pirali C, Buraschi R, Arienti C, Corbellini C, Negrini S. Moving forward in fall prevention: an intervention to improve balance among patients in a quasi-experimental study of hospitalized patients. Int J Rehabil Res 2015; 38: 313-9.

17. Żak M, Krupnik SZ, Puzio G, Staszczak-Gawelda I, Czesak J. Assessment of functional capability and on-going falls-risk in older institutionalized people after total hip arthroplasty for femoral neck fractures. Arch Gerontol Geriatrics 2015; 61: 14-20.

18. Manckoundia P, Taroux M, Kubicki A, Mourey F. Impact of ambulatory physiotherapy on motor abilities of elderly subjects with Alzheimer's disease. Geriatr Gerontol Int 2014; 14: 167-75.

19. da Silva KN, Teixeira LE, Imoto AM, Atallah AN, Peccin MS, Trevisani VF. Effectiveness of sensorimotor training in patients with rheumatoid arthritis: a randomized controlled trial. Rheumatol Int 2013; 33: 2269-75.

20. Howe TE, Rochester L, Neil F, Skelton DA, Ballinger C. Exercise for improving balance in older people. Cochrane Database Syst Rev 2011; 11: CD004963.

21. Kemmier W, Weineck J, Kalender WA, Engelke K. The effect of habitual physical activity, non-athetic exercise, muscle strength, and VO2max on bone mineral density is rather low in early postmenopausal osteopenic women. J Musculoskel Neuronal Interact 2004; 4: 325-34.

22. Steffen T, Hacker T, Mollinger L. Age and gender related test performance in community- dwelling elderly people: Six Minute Walk Test, Berg Balance Scale, Timed Up\&Go test and Gait Speeds. Phys Ther 2002; 82: 128-37.

\section{Address for correspondence:}

\section{Beata Szczepanowska-Wołowiec PhD}

Institute of Physiotherapy

Faculty of Medicine and Health Science

Jan Kochanowski University

al. IX Wieków Kielc 19, 25-317 Kielce, Poland

Phone: +48 604144751

E-mail: beatawolowiec@op.pl 